\title{
Synthesis and properties of sulfur-functionalized triarylmethylium, acridinium and triangulenium dyes
}

\author{
Marco Santella, Eduardo Della Pia, Jakob Kryger Sørensen and Bo W. Laursen ${ }^{*}$
}

\author{
Full Research Paper \\ Address: \\ Nano-Science Center and Department of Chemistry, University of \\ Copenhagen, Universitetsparken 5, 2100 Copenhagen $\varnothing$, Denmark \\ Email: \\ Bo W. Laursen* - bwl@nano.ku.dk \\ * Corresponding author \\ Keywords: \\ acridinium dyes; aromatic nucleophilic substitution; fluorescent dyes; \\ sulfur-functionalized dyes; triangulenium dyes; triarylmethylium
}

Beilstein J. Org. Chem. 2019, 15, 2133-2141. doi:10.3762/bjoc. 15.210

Received: 28 June 2019

Accepted: 23 August 2019

Published: 09 September 2019

This article is part of the thematic issue "Dyes in modern organic chemistry".

Guest Editor: H. Ihmels

(C) 2019 Santella et al.; licensee Beilstein-Institut. License and terms: see end of document.

\begin{abstract}
Triangulenium dyes functionalized with one, two or three ethylthiol functionalities were synthesized and their optical properties were studied. The sulfur functionalities were introduced by aromatic nucleophilic substitution of methoxy groups in triarylmethylium cations with ethanethiol followed by partial or full ring closure of the ortho positions with nitrogen or oxygen bridges leading to sulfur-functionalized acridinium, xanthenium or triangulenium dyes. For all the dye classes the sulfur functionalities are found to lead to intensely absorbing dyes in the visible range (470 to $515 \mathrm{~nm}$ ), quite similar to known analogous dye systems with dialkylamino donor groups in place of the ethylthiol substituents. For the triangulenium derivatives significant fluorescence was observed $\left(\Phi_{\mathrm{f}}=0.1\right.$ to $\left.\Phi_{\mathrm{f}}=0.3\right)$.
\end{abstract}

\section{Introduction}

The design, synthesis and studies of organic fluorescent dyes have witnessed a revival in recent years, in particular due to their applications in imaging and biomedical assays and analytical techniques [1-5]. The desire to detect minute amounts of dye, ideally single molecules [6,7], in complex biological environments with high levels of autofluorescence, constantly challenges chemists to develop new dyes with improved or special properties. In the design of simple dyes parameters such as molar absorption coefficients $(\varepsilon)$, absorption/emission wave- lengths $[8,9]$, fluorescence quantum yields $\left(\Phi_{\mathrm{fl}}\right)[10,11]$, and fluorescence lifetime $\left(\tau_{\mathrm{fl}}\right)[12,13]$ are key photophysical properties to consider and optimize for any given application.

We have for quite some time been interested in the synthesis, properties and applications of dyes from the triangulenium family (Figure 1) [14,15]. The triangulenium dyes can be divided into two main categories: 1) triangulenium dyes with donor substituents at the corners of the triangulenium ring 
<smiles></smiles>

$$
\begin{array}{ll}
X=O, R^{1}=R^{2}=R^{3}=N_{2} & A_{3} \text {-TOTA } \\
X=O, R^{1}=R^{2}=N R_{2}, R^{3}=H & A_{2} \text {-TOTA } \\
X=O, R^{1}=N R_{2}, R^{2}=R^{3}=H & A_{1} \text {-TOTA } \\
X=N R, R^{1}=R^{2}=R^{3}=N_{2} & A_{3} \text {-ADOTA } \\
X=O, R^{1}=R^{2}=R^{3}=O H & \text { H-TOTA }
\end{array}
$$

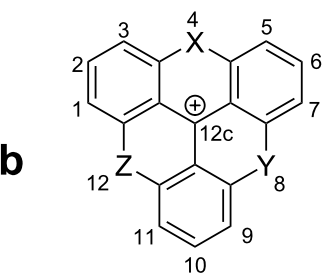

$$
\begin{array}{ll}
X=Y=Z=O & \text { TOTA } \\
X=N R, Y=Z=O & \text { ADOTA } \\
X=Y=N R, Z=O & \text { DAOTA } \\
X=Y=Z=N R & \text { TATA } \\
X=S, Y=Z=O & \text { DOTTA } \\
X=S, Y=N R, Z=O & \text { AOTTA }
\end{array}
$$

Figure 1: Structures of some representative triangulenium dyes. a) Rhodamine/fluorescine-like derivatives with donor groups in para-positions (2, 6 , and 10) to the formal cation center (12c). b) Derivatives without donor groups.

system (position 2, 6 and 10, Figure 1a) [16-18], and 2) triangulenium dyes without such groups (Figure 1b) [19-21]. Dyes in the first category have intense absorption $\left(\varepsilon \approx 50,000-130,000 \mathrm{M}^{-1} \cdot \mathrm{cm}^{-1}\right)$, high fluorescence quantum yields $\left(\Phi_{\mathrm{fl}}>50 \%\right)$ and fluorescence lifetimes of 3-4 ns. All properties that agree well with their structural resemblance to rhodamines and fluoresceines, and triangulenium dyes such as $\mathrm{A}_{3}$-TOTA ${ }^{+}$and H-TOTA ${ }^{+}$(Figure 1a) can be viewed as extended symmetric versions of these prominent dyes $[16,22]$. The second class of triangulenium dyes, without appended donor groups, are characterized by much less intense transitions $\left(\varepsilon \approx 5,000-20,000 \mathrm{M}^{-1} \cdot \mathrm{cm}^{-1}\right)$, which for some derivatives leads to unusually long fluorescence lifetimes $\left(\tau_{\mathrm{fl}} \approx 20 \mathrm{~ns}\right)[23,24]$. This long fluorescence lifetime has been a key point of interest since it enables time-gated detection for suppression of autofluorescence $[25,26]$ and provides attractive advantages in fluorescence polarization assays $[13,27,28]$.

A common characteristic feature of triangulenium dye synthesis is the use of methoxy-substituted triarylmethylium salts as simple precursors allowing both introduction of dialkylamino donor groups and formation of the heterocyclic triangulenium ring systems. These characteristic types of aromatic nucleophilic substitution $\left(\mathrm{S}_{\mathrm{N}} \mathrm{Ar}\right)$ reactions are exemplified by the synthesis of $\mathrm{A}_{3}-\mathrm{ADOTA}^{+}$(Figure 2) [17]. Starting from the readily available tris(2,4,6-trimethoxyphenyl)methylium salt (TMP) ${ }_{3} \mathrm{C}^{+}$ $[18,29]$, stepwise replacement of the para-methoxy groups by dialkylamines provides access to a wide variety of symmetric and asymmetric triarylmethylium dyes [18,30,31]. Replacement of two $o$-methoxy groups by one primary amine gives acridinium-type ring systems (Figure 2, step 2) and is a key reaction for the formation of the unsubstituted triangulenium dyes shown in Figure 1b [19,20]. Finally, formation of oxygen bridges in the triangulenium system (Figure 2, step 3) involves demethylation conditions and intramolecular $\mathrm{S}_{\mathrm{N}} \mathrm{Ar}$ replacement of ortho-methoxy groups [18,32].

The $\mathrm{S}_{\mathrm{N}} \mathrm{Ar}$ approach to the synthesis of triangulenium dyes $[14,18,19]$ has been extremely successful and expanded the family greatly from the single derivative $\left(\mathrm{TOTA}^{+}\right.$, Figure $\left.1 \mathrm{~b}\right)$

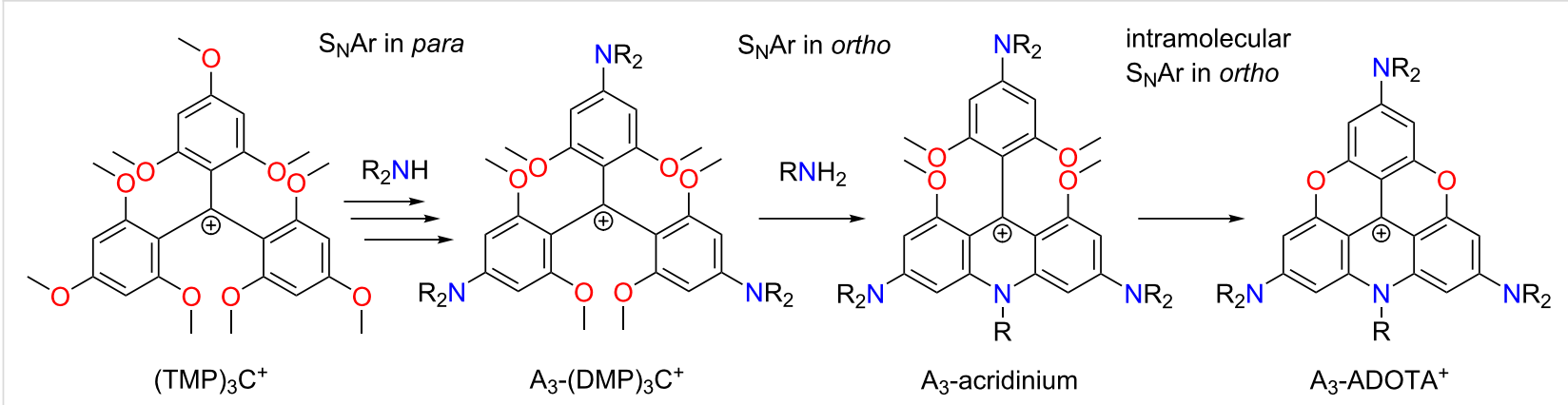

Figure 2: Examples of various types of $S_{N} A r$ reactions typical in triangulenium synthesis, exemplified with the synthesis of $A_{3}-A D O T A^{+}$: step 1, replacement of $p$-methoxy groups with dialkylamines. Step 2, replacement of $o$-methoxy groups with a primary amine followed by intramolecular $S_{N} A r$ reaction. Step 3, intramolecular $S_{N} A r$ replacement of methoxy groups by hydroxy groups formed under ether-cleavage conditions. 
first synthesized by Martin and Smith in 1964 [32], and also includes the family of helicenium dyes [33-35]. However, the introduction of groups other than nitrogen and oxygen has so far not been performed by the $\mathrm{S}_{\mathrm{N}} \mathrm{Ar}$ approach. Thus in the preparation of the sulfur-bridged triangulenium ions DOTTA $^{+}$and AOTTA $^{+}$(Figure 1b) Lacour and co-workers reported unsuccessful attempts of $\mathrm{S}_{\mathrm{N}} \mathrm{Ar}$ reactions with sulfur nucleophiles in ortho-position of (TMP) ${ }_{3} \mathrm{C}^{+}$and had to assemble the thioxanthenium part of the triangulenium ring system independently by other means [36]. Similarly, we had to use a stepwise buildup of the triangulenium systems to introduce saturated [37] and unsaturated [38] carbon bridges.

Here we report for the first time the introduction of sulfur functionalities into triangulenium dyes by $\mathrm{S}_{\mathrm{N}} \mathrm{Ar}$ reaction with ethylthiol nucleophiles in the para-positions accessing several new families of xanthenium, acridinium and triangulenium dyes with thioether donor groups.

\section{Results and Discussion}

Firstly, a series of triarylmethylium salts with variable number of para-methoxy substituents was synthesized. The easily achievable cations $(\mathrm{TMP})_{3} \mathrm{C}^{+},(\mathrm{DMP})(\mathrm{TMP})_{2} \mathrm{C}^{+}$and $(\mathrm{DMP})_{2}(\mathrm{TMP}) \mathrm{C}^{+}$(Scheme 1$)$ were prepared by their respective literature procedures $[18,31]$. To investigate the reactivity of these carbenium systems in $S_{N} A r$ reactions with sulfur-based nucleophiles, simple alkylthiols were chosen, with the ethyl and tert-butyl thiols being the primary choice. $\mathrm{S}_{\mathrm{N}} \mathrm{Ar}$ reactions with the two thiols were tested under identical reaction conditions (Scheme 1).

These conditions consisted of heating the reaction components in refluxing acetonitrile in the presence of collidine as base. For all three carbenium salts examinations showed that only ethanethiol lead to substitution. The progress of the reaction was conveniently followed by MALDI-TOF mass spectrome- try. In case of the reactions with tert-butylthiolate, neither detection of the target molecule nor any of the intermediates were observed. This lack of reactivity is likely explained by the tert-butylthiolate nucleophile being too bulky to undergo reaction. In the successful reactions, which had occurred with ethanethiol, a high selectivity was observed for para-substitutions, giving $\mathrm{S}_{\mathrm{x}}-(\mathrm{DMP}){ }_{3} \mathrm{C}^{+} \mathbf{1}, \mathbf{2}$, and $\mathbf{3}$ in reasonable yields of $20-50 \%$ after column chromatography purification. It is important to note that the gradual introduction of thioethers into the carbenium systems did not significantly influence the overall reactivity of the system towards subsequent nucleophilic aromatic substitution. When the reaction was followed by MALDI-TOFMS spectrometry it was thus possible to observe simultaneously the presence of the target compound and all of the intermediates involved in the reaction. This behavior is contrary to the reaction pattern observed when using dialkylamines as nucleophiles, where the strong electron-donating effect of the introduced amines stabilize the carbenium ion products and thus significantly reduces the reactivity of the remaining methoxy groups for further substitutions [18,39]. This observation is in agreement with the much stronger cation stabilization of the dialkylamino group compared to the methoxy group. The ability of the alkylthio group to stabilize carbenium ions, given by the Hammet $\sigma_{\mathrm{p}}{ }^{+}$value [40], on the other hand is quite similar to the methoxy group or even a little lower [41], and does thus not slow down the multistep $S_{N} A r$ reactions.

The new ortho-methoxytriarylcarbenium ions with one, two and three para-SEt groups (1-3) are potential precursors for a wide variety of new triangulenium, xanthenium, and acridinium dyes. To elucidate some of these possibilities we first investigated transformations of the symmetric derivative $\mathbf{1}$. Treatment with primary alkylamines, $n$-propylamine and $n$-octylamine, yielded exclusively the acridinium products $\mathbf{4 a}, \mathbf{b}$ (Scheme 2 ). This ortho $\mathrm{S}_{\mathrm{N}} \mathrm{Ar}$ transformation is similar to what is reported for the $(\mathrm{DMP})_{3} \mathrm{C}^{+}$system $[19,20,42]$ lacking para-substituents and for<smiles>[X]c1cc(OC)c([C](c2c(OC)cc([X])cc2OC)c2c(OC)cc(OC)cc2OC)c(OC)c1</smiles>

$$
\begin{array}{ll}
X^{1}=X^{2}=- \text { OMe } & (\text { TMP })_{3} C^{+} \\
X^{1}=H, X^{2}=-O M e & (\text { DMP })(T M P)_{2} C^{+} \\
X^{1}=X^{2}=H & (D M P)_{2}(T M P) C^{+}
\end{array}
$$<smiles>[Y2]c1cc(OC)c([C](c2c(OC)cc([Y2])cc2OC)c2c(OC)cc(SCC)cc2OC)c(OC)c1</smiles>

$$
\begin{aligned}
& \mathrm{Y}^{1}=\mathrm{Y}^{2}=\text {-SEt } \quad \mathrm{S}_{3}-(\mathrm{DMP})_{3} \mathrm{C}^{+} \quad 1,51 \% \\
& \mathrm{Y}^{1}=\mathrm{H}, \mathrm{Y}^{2}=\text {-SEt } \mathrm{S}_{2}-(\mathrm{DMP})_{3} \mathrm{C}^{+} \quad 2,39 \% \\
& Y^{1}=Y^{2}=H \quad S_{1}-(D M P)_{3} C^{+} \quad 3,21 \%
\end{aligned}
$$




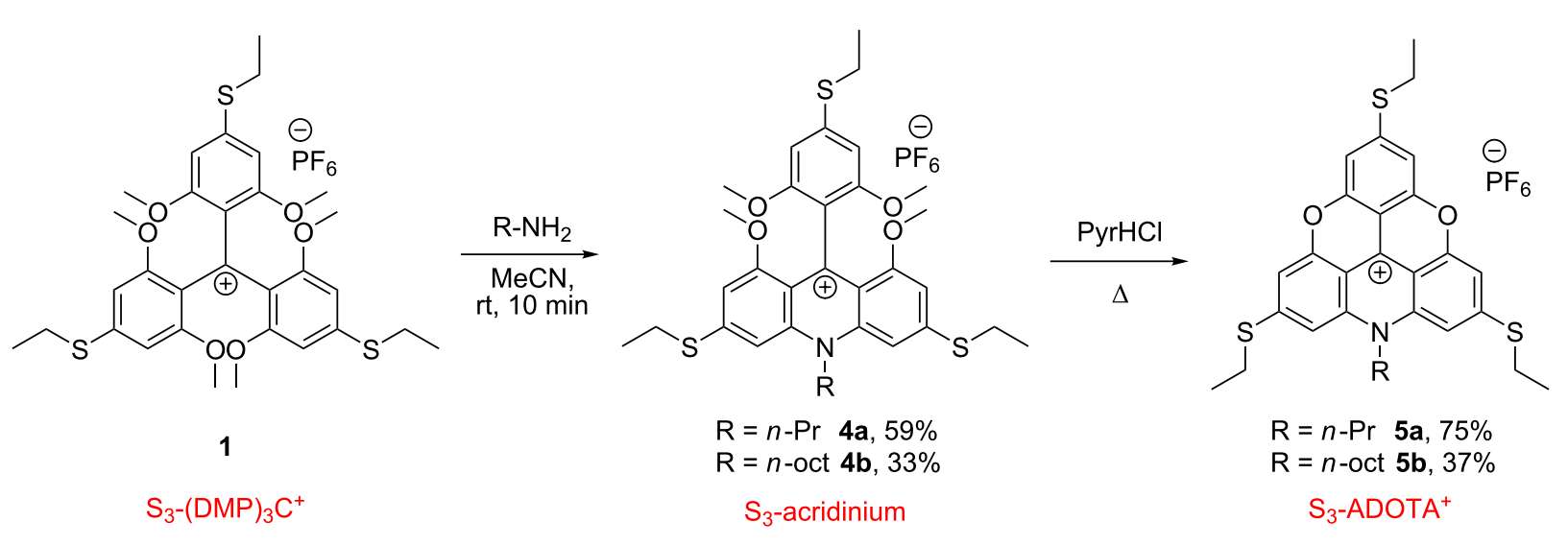

Scheme 2: Synthetic route for the synthesis of $\mathrm{S}_{3}-\mathrm{ADOTA}^{+}$.

the para-amino-substituted analogue [17] (step 2 in Figure 1). It was found that the reactivity in $\mathrm{S}_{\mathrm{N}} \mathrm{Ar}$ reactions of $\mathbf{1}$ with primary amines was high and the acridinium compounds $\mathbf{4 a}, \mathbf{b}$ were obtained in few minutes after the addition of 2 equiv of the corresponding primary amine at room temperature. Further ring closure to two oxygen bridges in acridinium compounds $\mathbf{4 a}$ and $4 \mathbf{b}$ to the corresponding triangulenium dyes $\mathrm{S}_{3}-\mathrm{ADOTA}^{+}(\mathbf{5 a}, \mathbf{b})$ was achieved by heating in molten pyridine hydrochloride (Scheme 2).

It is noteworthy that the ethylthio ether linkages remained intact upon treatment with molten $\mathrm{PyrHCl}$, which was found to result in complicated mixtures of dealkylated byproducts when these conditions were applied on dialkylamino-substituted carbenium systems [18].

The direct ring closure of $\mathbf{1}$ in $\mathrm{PyrHCl}$ yielded in a similar manner the sulfur-functionalized trioxatriangulenium system $\mathrm{S}_{3}$-TOTA ${ }^{+}$(6) as shown in Scheme 3. Mono ring closure was achieved under milder ether cleaving conditions with aqueous
$\mathrm{HBr}$ in acetic acid, leading to the ethylthio-substituted xanthenium system 7 in $43 \%$ yield (Scheme 3 ).

By applying similar molten pyridine hydrochloride conditions to the mono- and disubstituted thioether carbenium salts ( 2 and 3), it was possible to isolate the derivatives $\mathrm{S}_{2}$-TOTA ${ }^{+}(\mathbf{8})$ and $\mathrm{S}_{1}$-TOTA ${ }^{+}(\mathbf{9})$, respectively as their hexafluorophosphate salts (Scheme 4). The two $\mathrm{S}_{\mathrm{X}}$-TOTA ${ }^{+}$derivatives were obtained with good yield after purification by column chromatography and subsequent recrystallization.

To conclude, the successful introduction of -SEt groups by the $\mathrm{S}_{\mathrm{N}} \mathrm{Ar}$ approach, and subsequent nitrogen and oxygen ringclosure reactions provides access to several new families of carbenium dyes, all with the unusual -SR donor group: thus 1-3 represent new triarylmethylium dyes, $\mathbf{4 a}$ and $\mathbf{4 b}$ sulfur analogues of aminoacridinium dyes (acridine orange-like structures), 7 a fluorescein-like xanthenium dye, $\mathbf{5 a}$ and $\mathbf{5 b}$ are sulfur-substituted ADOTA $^{+}$dyes, and finally the three sulfursubstituted TOTA ${ }^{+}$dyes $\mathbf{6}, \mathbf{8}$ and $\mathbf{9}$.

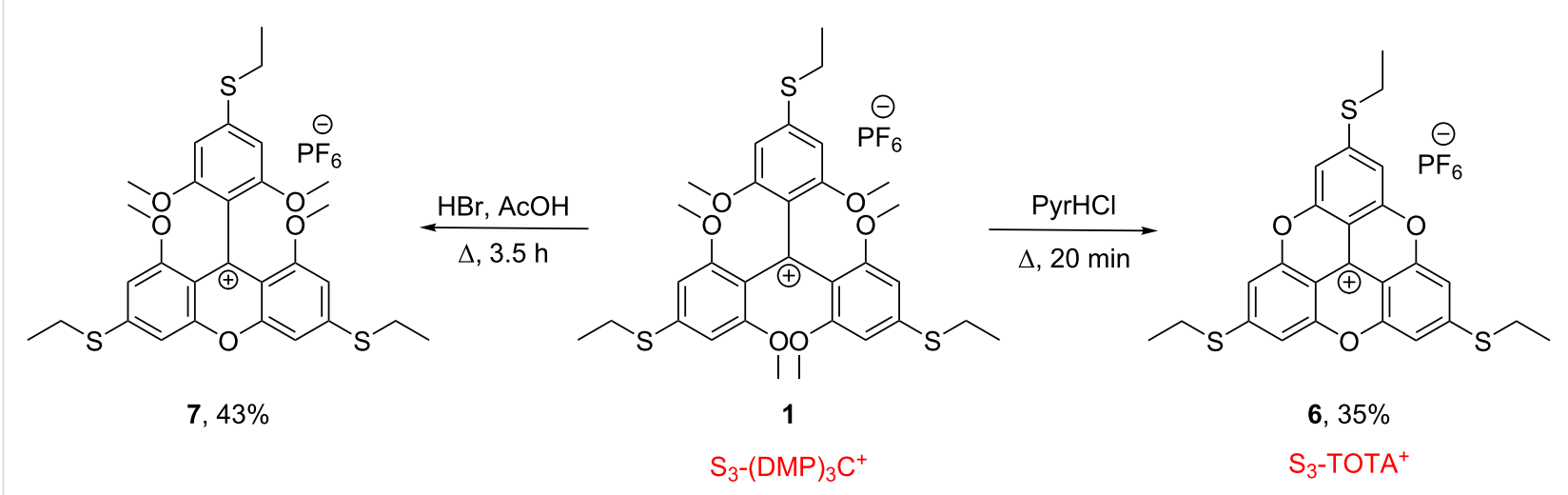

Scheme 3: Synthesis of $\mathrm{S}_{3}-\mathrm{TOTA}^{+} \mathrm{PF}_{6}{ }^{-}(6)$ and the mono ring closed xanthenium 7. 


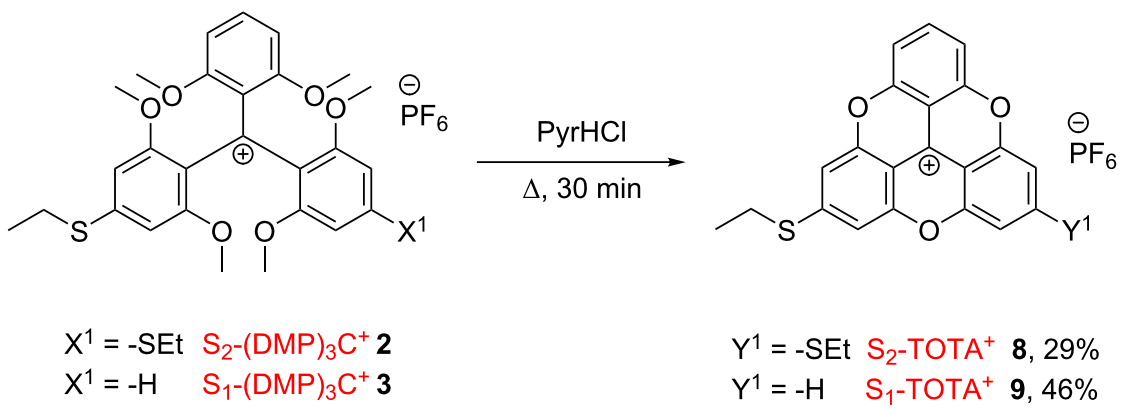

Scheme 4: Synthesis of $\mathrm{S}_{2}-\mathrm{TOTA}^{+} \mathrm{PF}_{6}^{-}(\mathbf{8})$ and $\mathrm{S}_{1}-\mathrm{TOTA}^{+} \mathrm{PF}_{6}^{-}$(9).

Now the relevant questions are: how do the -SR donor groups influence transition energies and intensities? And how do they affect fluorescence quantum yields in these new dye systems? To the extent possible we will compare the new sulfur-functionalized dyes to known analogues with $-\mathrm{OR}$ or $-\mathrm{NR}_{2}$ donor groups in the same positions.

The sulfur-substituted triarylmethylium dyes 1, $\mathbf{2}$ and $\mathbf{3}$ display broad absorption bands in the 500-700 nm region (Figure 3), that in shape and relative transition energy are quite similar to the analogues with similar numbers of para-methoxy or diethylamino groups [31], as shown by comparison of maximum absorption wavelength ( $\left.\lambda_{\max , a b s}\right)$ and molar absorptivity $(\varepsilon)$ in Table 1. It is noticed that the -SEt donor group in these orthohexamethoxytriarylmethylium dyes provides transition energies and intensities very similar to those of commonly used dialkylamino-donor groups, but significantly red-shifted relative to the methoxy-substituted analogues.

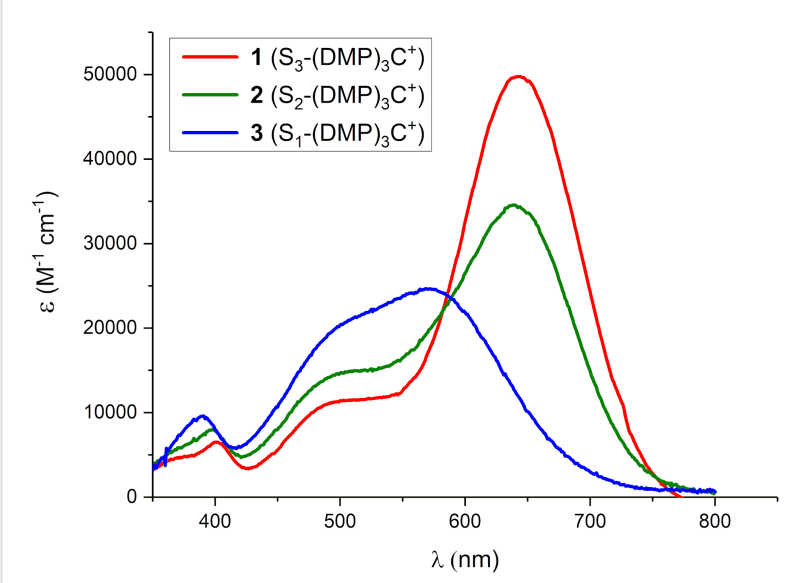

Figure 3: UV-vis spectra in $\mathrm{MeCN}: \mathrm{S}_{3}-(\mathrm{DMP})_{3} \mathrm{C}^{+}(\mathbf{1}$, red), $\mathrm{S}_{2}-(\mathrm{DMP})_{3} \mathrm{C}^{+}(2$, green $)$, and $\mathrm{S}_{1}-(\mathrm{DMP})_{3} \mathrm{C}^{+}(3$, blue $)$.

Absorption spectra of the partially ring-closed acridinium and xanthenium compounds, with three para-SEt groups, $\mathbf{4 a}$ and $\mathbf{7}$,
Table 1: Summary of absorption data of triarylmethylium ions in MeCN.<smiles></smiles>

\begin{tabular}{lcll}
\hline & \multicolumn{3}{c}{$\lambda_{\text {max.abs. }}\left(\varepsilon, \mathrm{M}^{-1} \cdot \mathrm{cm}^{-1}\right)$} \\
\cline { 2 - 4 } donor groups & $-\mathrm{SEt}$ & $-\mathrm{OMe}^{\mathrm{a}}$ & $-\mathrm{NEt}_{2}{ }^{\mathrm{a}}$ \\
$\mathrm{R}^{1}, \mathrm{R}^{2}, \mathrm{R}^{3}$ & & & \\
\hline one donor & $576 \mathrm{~nm}$ & $491 \mathrm{~nm}$ & $457 \mathrm{~nm}$ \\
$\mathrm{R}^{2}=\mathrm{R}^{3}=\mathrm{H}$ & $(24600)$ & $(14100)$ & $(16900)$ \\
two donors & $639 \mathrm{~nm}$ & $580 \mathrm{~nm}$ & $637 \mathrm{~nm}$ \\
$\mathrm{R}^{3}=\mathrm{H}$ & $(34600)$ & $(18400)$ & $(40400)$ \\
three donors & $642 \mathrm{~nm}$ & $577 \mathrm{~nm}$ & $634 \mathrm{~nm}$ \\
& $(49800)$ & $(23400)$ & $(49400)$ \\
\hline
\end{tabular}

aData from $[43,44]$.

respectively, are shown in Figure 4. For these compounds the spectra are dominated by strong transitions assigned to the 3,6-diethylthio-acridinium and -xanthenium ring systems peaking at $457 \mathrm{~nm}\left(\varepsilon=47000 \mathrm{M}^{-1} \cdot \mathrm{cm}^{-1}\right)$ and at $520 \mathrm{~nm}$ ( $\varepsilon=60000 \mathrm{M}^{-1} \cdot \mathrm{cm}^{-1}$ ), respectively (see Supporting Information File 1, Table S1 for additional data in more solvents). The energy and intensity of these transitions are quite similar to those found in dialkylamino analogues, that are 3,6diaminoacridines and rhodamines $[43,44]$. The weak tails on the red side of these bands are tentatively assigned to internal charge-transfer transitions from the perpendicularly $[19,42]$ arranged ethylthio(dimethoxy)phenyl group to the xanthenium/ acridinium systems polarized along the $y$-axes (Figure 4, inset). This bichromophoric behavior has been studied in detail for the dialkylamino-substituted xanthenium/rhodamine system $[45,46]$, and is also the likely reason for these compounds being non-fluorescent. 


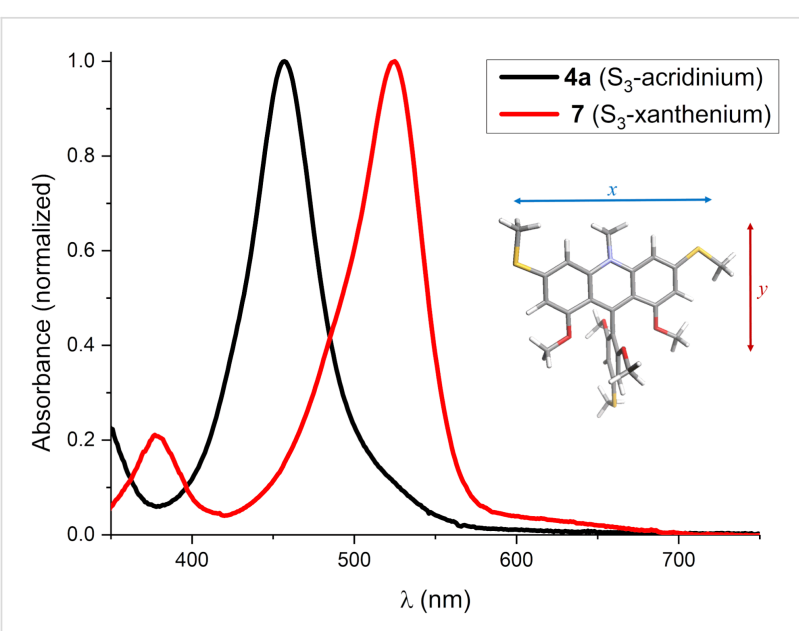

Figure 4: UV-vis spectra in $\mathrm{MeCN}: \mathrm{S}_{3}$-acridinium (4a, black) and $\mathrm{S}_{3}$-xanthenium $(7, \mathrm{red})$. Inset: The 3D structure of $4 \mathrm{a}$ with indication of the principle axes of the electronic transitions.

The three sulfur-substituted trioxatriangulenium dyes $\mathbf{6}, \mathbf{8}$, and 9 all display a first absorption band around $480 \mathrm{~nm}$ (Figure 5), with increasing intensity as the number of -SEt groups on the TOTA $^{+}$core increases. This behavior resembles the trend observed for the analogue series of amino-substituted TOTA's (Table 2) [18,31]. In the two low-symmetry derivatives 8 and 9 transitions to the $S_{2}$ excited states are observed at around $400 \mathrm{~nm}$, while the $D_{3 h}$ symmetric $\mathrm{S}_{3}$-TOTA ${ }^{+}$shows only one, though broad, absorption band corresponding to merging of the $S_{1}$ and $S_{2}$ transitions into one, arising from the degenerated HOMO in the symmetric dye. The influence of solvent and counter ions on such degenerate states have been studied in detail for the $\mathrm{A}_{3}$-TOTA system $[22,47]$ and related triarylmethylium dyes such as crystal violet $[48,49]$.

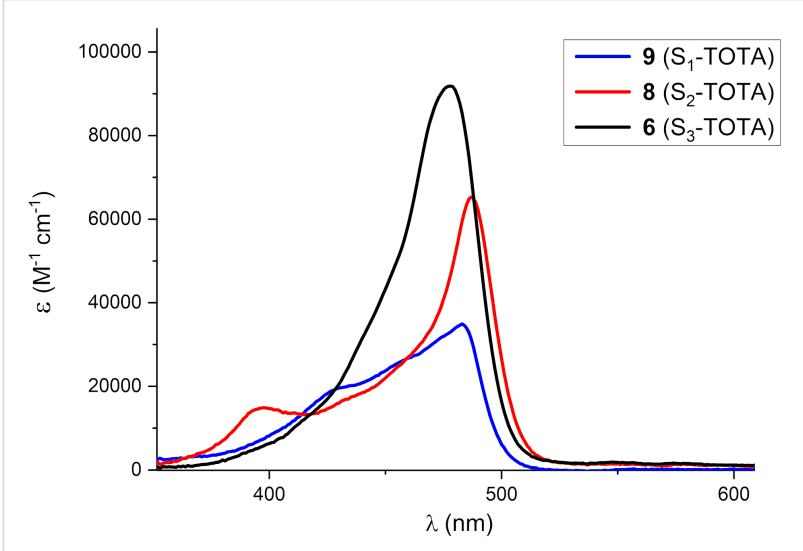

Figure 5: UV-vis spectra in $\mathrm{CH}_{2} \mathrm{Cl}_{2}: \mathrm{S}_{1}-\mathrm{TOTA}^{+}(\mathbf{9}$, blue line), $\mathrm{S}_{2}-$ TOTA $^{+}(8$, red line $)$, and $\mathrm{S}_{3}-$ TOTA $^{+}(6$, black line $)$.

When three -SEt groups are placed on the asymmetric azadioxatriangulenium core, as in $\mathrm{S}_{3}-\mathrm{ADOTA}^{+}(\mathbf{5 a})$, the presence of two
Table 2: Summary of absorption data of substituted TOTA dyes in $\mathrm{CH}_{2} \mathrm{Cl}_{2}$.<smiles></smiles>

\begin{tabular}{|c|c|c|}
\hline \multirow[b]{2}{*}{$\begin{array}{l}\text { Donor groups } \\
R^{1}, R^{2}, R^{3}\end{array}$} & \multicolumn{2}{|c|}{$\lambda_{\max , a b s}\left(\varepsilon, \mathrm{M}^{-1} \cdot \mathrm{cm}^{-1}\right)$} \\
\hline & -SEt & $-\mathrm{NEt}_{2}$ \\
\hline $\begin{array}{l}\text { one donor } \\
R^{2}=R^{3}=H\end{array}$ & $\begin{array}{c}\mathrm{S}_{1}-\mathrm{TOTA}^{+}(\mathbf{9}) \\
483 \mathrm{~nm} \\
(35000)\end{array}$ & $\begin{array}{c}\mathrm{A}_{1}-\mathrm{TOTA}^{+\mathrm{a}} \\
507 \mathrm{~nm} \\
(41700)\end{array}$ \\
\hline $\begin{array}{l}\text { two donors } \\
\mathrm{R}^{3}=\mathrm{H}\end{array}$ & $\begin{array}{c}\mathrm{S}_{2}-\mathrm{TOTA}^{+}(\mathbf{8}) \\
487 \mathrm{~nm} \\
(65200)\end{array}$ & $\begin{array}{c}\mathrm{A}_{2}-\mathrm{TOTA}^{+\mathrm{a}} \\
513 \mathrm{~nm} \\
(59700)\end{array}$ \\
\hline three donors & $\begin{array}{c}\mathrm{S}_{3}-\mathrm{TOTA}^{+}(6) \\
478 \mathrm{~nm} \\
(91900)\end{array}$ & $\begin{array}{c}\text { A }_{3}-\text { TOTA }^{+b} \\
471 \mathrm{~nm} \\
(132900)\end{array}$ \\
\hline
\end{tabular}

aData from [31]; ${ }^{b}$ data from [18].

electronic transitions becomes very clear, with two wellresolved peaks in the absorption spectrum (Figure 6). The transition at $442 \mathrm{~nm}$ is assigned to the $S_{0} \rightarrow S_{2}$ transition and nearly coincides with the main transition observed in the $\mathrm{S}_{3}$-acridinium (4a) precursor before ring closure (Figure 4), indicating that this, the most intense transition belongs to the same chromophore, now part of the triangulenium ring system. The $\mathrm{S}_{0} \rightarrow \mathrm{S}_{1}$ transition in $\mathbf{5 a}$ is found at $507 \mathrm{~nm}$, where the open form only had a very weak shoulder in its absorption spectrum (Figure 4). The ring closure of $\mathbf{4 a}$ into the fully planar triangulenium system 5a leads to a significant increase in the orbital overlap and thus also in the intensity of the $S_{0} \rightarrow S_{1}$ transition. This assignment is supported by calculations of the orbitals involved in the first two electronic transitions (Figure 6), which confirm their localization in different parts of the ADOTA $^{+}$ system. The much more allowed $\mathrm{S}_{0} \rightarrow \mathrm{S}_{1}$ transition is also in agreement with the observation that $5 \mathbf{a}$ (and $\mathbf{5 b}$ ) display intense fluorescence (Figure 6).

Table 3 summarizes the spectral and photophysical properties on the triangulenium dyes showing any applicable fluorescence. Beside $\mathrm{S}_{3}-\mathrm{ADOTA}^{+}$(5a) that are the double and triple -SEtsubstituted TOTAs $\mathbf{6}$ and $\mathbf{8}$, for which the fluorescence spectra are shown in Figure 7, with fluorescence quantum yields of $16 \%$ and $12 \%$, respectively. From the measured fluorescence lifetimes and quantum yields (Table 3 ) it is possible to calculate the radiative lifetimes $\left(\tau_{0}\right)$, which are found to be in qualita- 


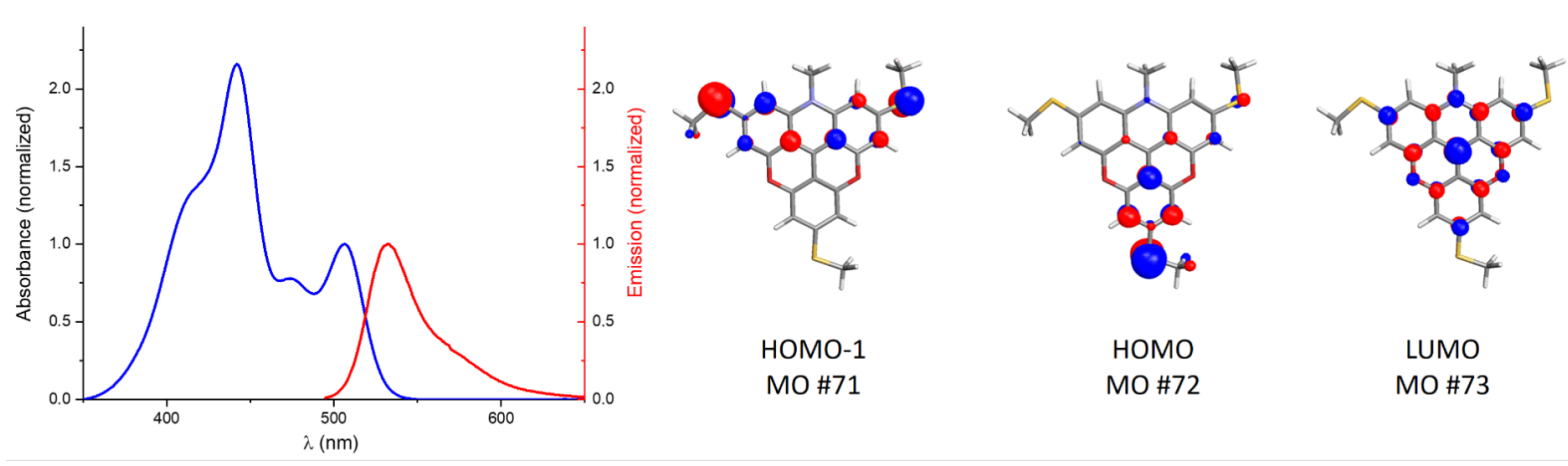

Figure 6: UV-vis absorption and fluorescence spectra $\left(\lambda_{\mathrm{ex}}=485 \mathrm{~nm}\right)$ of $5 \mathrm{a}$ in $\mathrm{CH}_{2} \mathrm{Cl}_{2}$ solution. Calculated molecular orbital contour plots (semiempirical method AM1).

Table 3: Summary of optical properties of the fluorescent derivatives.

\begin{tabular}{|c|c|c|c|c|c|c|c|}
\hline Compound & Solvent & $\lambda_{\max , \operatorname{abs}}(\mathrm{nm})$ & $\varepsilon\left(\mathrm{M}^{-1} \cdot \mathrm{cm}^{-1}\right)$ & $\lambda_{\max , f l}(n m)$ & $\Phi_{\mathrm{f}}^{\mathrm{a}}$ & $\mathrm{T}(\mathrm{ns})$ & $\mathrm{T}_{0} \mathrm{~b}(\mathrm{~ns})$ \\
\hline $5 \mathbf{a}\left(\mathrm{S}_{3}-\mathrm{ADOTA}\right)$ & $\mathrm{CH}_{2} \mathrm{Cl}_{2}$ & $\begin{array}{l}442 \\
507\end{array}$ & $\begin{array}{l}76700 \\
35400\end{array}$ & 532 & 0.28 & 3.9 & 13.9 \\
\hline $6\left(\mathrm{~S}_{3}-\mathrm{TOTA}\right)$ & $\mathrm{CH}_{2} \mathrm{Cl}_{2}$ & 478 & 91850 & 505 & 0.16 & 0.7 & 4.4 \\
\hline 8 (S 2 -TOTA $)$ & $\mathrm{CH}_{2} \mathrm{Cl}_{2}$ & 487 & 65200 & 509 & 0.12 & 0.7 & 5.8 \\
\hline
\end{tabular}

a Measured relative to fluorescein in $0.1 \mathrm{M}$ aqueous $\mathrm{NaOH}(\Phi=0.96) ;{ }^{b}$ radiative lifetime $\mathrm{T}_{0}=\Phi_{\mathrm{f}} / \mathrm{T}$.

tive agreement with the molar absorption coefficients $(\varepsilon)$ for the corresponding transitions, as expected from the Strickler-Berg relation [50].

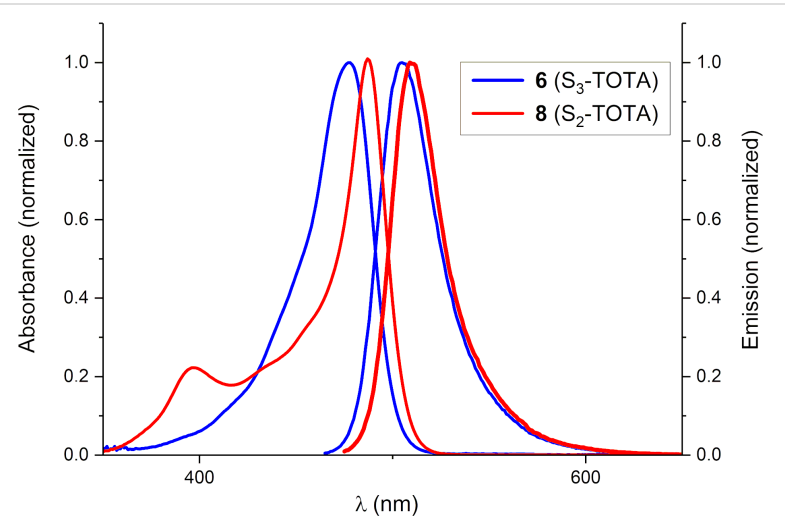

Figure 7: Normalized absorption and fluorescence spectra of $6\left(\mathrm{~S}_{3}\right.$ TOTA $\left.{ }^{+}\right), \lambda_{\mathrm{ex}}=460 \mathrm{~nm}$, and $8\left(\mathrm{~S}_{2}-\mathrm{TOTA}^{+}\right), \lambda_{\mathrm{ex}}=470 \mathrm{~nm}$, in $\mathrm{CH}_{2} \mathrm{Cl}_{2}$ solution.

While the spectral properties of the new -SEt-substituted dyes are surprisingly similar to the $-\mathrm{NEt}_{2}$-substituted analogues across the various dye families they are obviously less bright fluorophores. Thus, the dialkylamino-substituted analogue of $\mathbf{5 a}$ $\left(\mathrm{A}_{3}-\mathrm{ADOTA}^{+}\right)$has a reported quantum yield as high as $64 \%$ in acetonitrile [17], on par with $\mathrm{A}_{3}$-TOTA ${ }^{+}$and $\mathrm{A}_{2}$-TOTA ${ }^{+}$which display quantum yields from $50-100 \%$ depending on the solvent [31]. A similar reduction in fluorescence efficiency was observed by Kotaskova et al. for fluorescein derivatives with one alkylthio group in the 3 position replacing an $-\mathrm{OH} /-\mathrm{O}^{-}$ group [51]. The origin of reduced fluorescence quantum yields in dyes with alkylthio donor groups in their chromophores is not clear at this point. It may result from enhanced internal conversion or intersystem crossing to the triplet state. Further photophysical work will have to settle this issue and thereby suggest structural improvements and/or the best applications of these dyes.

\section{Conclusion}

The effective introduction of alkylthiol groups into the para-positions of triarylmethylium ions via $S_{N} A r$ reactions was demonstrated. These new thioether-substituted triarylmethylium ions provide access to a broad range of new heterocyclic carbenium dyes of the xanthenium, acridinium and triangulenium type via further $\mathrm{S}_{\mathrm{N}} \mathrm{Ar}$ reactions with primary amines and ring-closure reactions. The introduction of thioether donor groups in these dye classes is unprecedented, but is found to yield spectral properties quite similar to analogous dyes with dialkylamino groups. The synthesized thioether-substituted triangulenium derivatives are fluorescent, though with lower quantum yields $\left(\Phi_{\mathrm{f}}=0.1\right.$ to $\left.\Phi_{\mathrm{f}}=0.3\right)$ than the corresponding dialkylaminosubstituted analogues. 


\section{Supporting Information}

\section{Supporting Information File 1}

Experimental details, full synthetic procedures, spectroscopic characterization and NMR spectra of new compounds, as well as additional UV-vis and fluorescence spectra.

[https://www.beilstein-journals.org/bjoc/content/ supplementary/1860-5397-15-210-S1.pdf]

\section{Acknowledgements}

The work was supported by the Danish Council of Independent Research (DFF-6111-00483).

\section{ORCID ${ }^{\circledR}$ iDs}

Bo W. Laursen - https://orcid.org/0000-0002-1120-3191

\section{References}

1. Lavis, L. D.; Raines, R. T. ACS Chem. Biol. 2008, 3, 142-155. doi:10.1021/cb700248m

2. Grimm, J. B.; Muthusamy, A. K.; Liang, Y.; Brown, T. A.; Lemon, W. C.; Patel, R.; Lu, R.; Macklin, J. J.; Keller, P. J.; Ji, N.; Lavis, L. D. Nat. Methods 2017, 14, 987-994. doi:10.1038/nmeth.4403

3. Butkevich, A. N.; Lukinavičius, G.; D'Este, E.; Hell, S. W. J. Am. Chem. Soc. 2017, 139, 12378-12381. doi:10.1021/jacs.7b06412

4. Kolmakov, K.; Hebisch, E.; Wolfram, T.; Nordwig, L. A.; Wurm, C. A.; Ta, H.; Westphal, V.; Belov, V. N.; Hell, S. W. Chem. - Eur. J. 2015, 21, 13344-13356. doi:10.1002/chem.201501394

5. Haugland, R. P. The Molecular Probes Handbook, 11th ed.; Thermofischer Scientific, 2010.

6. Moerner, W. E.; Orrit, M. Science 1999, 283, 1670-1676. doi:10.1126/science.283.5408.1670

7. Grimm, J. B.; English, B. P.; Chen, J.; Slaughter, J. P.; Zhang, Z.; Revyakin, A.; Patel, R.; Macklin, J. J.; Normanno, D.; Singer, R. H.; Lionnet, T.; Lavis, L. D. Nat. Methods 2015, 12, 244-250. doi: $10.1038 /$ nmeth.3256

8. Lei, Z.; Li, X.; Luo, X.; He, H.; Zheng, J.; Qian, X.; Yang, Y. Angew. Chem., Int. Ed. 2017, 56, 2979-2983. doi:10.1002/anie.201612301

9. Staudinger, C.; Borisov, S. M. Methods Appl. Fluoresc. 2015, 3 , 042005. doi:10.1088/2050-6120/3/4/042005

10. Panchuk-Voloshina, N.; Haugland, R. P.; Bishop-Stewart, J.; Bhalgat, M. K.; Millard, P. J.; Mao, F.; Leung, W.-Y.; Haugland, R. P. J. Histochem. Cytochem. 1999, 47, 1179-1188. doi:10.1177/002215549904700910

11. Song, X.; Johnson, A.; Foley, J. J. Am. Chem. Soc. 2008, 130 , 17652-17653. doi:10.1021/ja8075617

12. Berezin, M. Y.; Achilefu, S. Chem. Rev. 2010, 110, 2641-2684. doi:10.1021/cr900343z

13. Meyer-Almes, F.-J. Methods Appl. Fluoresc. 2017, 5, 042002. doi:10.1088/2050-6120/aa7c7a

14. Bosson, J.; Gouin, J.; Lacour, J. Chem. Soc. Rev. 2014, 43, 2824-2840. doi:10.1039/c3cs60461f
15. Stępień, M.; Gońka, E.; Żyła, M.; Sprutta, N. Chem. Rev. 2017, 117, 3479-3716. doi:10.1021/acs.chemrev.6b00076

16. Westerlund, F.; Hildebrandt, C. B.; Sørensen, T. J.; Laursen, B. W. Chem. - Eur. J. 2010, 16, 2992-2996. doi:10.1002/chem.200902965

17. Laursen, B. W.; Sørensen, T. J. J. Org. Chem. 2009, 74, 3183-3185. doi:10.1021/jo9002486

18. Laursen, B. W.; Krebs, F. C.; Nielsen, M. F.; Bechgaard, K.; Christensen, J. B.; Harrit, N. J. Am. Chem. Soc. 1998, 120, 12255-12263. doi:10.1021/ja982550r

19. Laursen, B. W.; Krebs, F. C. Chem. - Eur. J. 2001, 7, 1773-1783. doi:10.1002/1521-3765(20010417)7:8<1773::aid-chem17730>3.0.co;2-

20. Laursen, B. W.; Krebs, F. C. Angew. Chem., Int. Ed. 2000, 39, 3432-3434. doi:10.1002/1521-3773(20001002)39:19<3432::aid-anie3432>3.0.co;2$\mathrm{s}$

21. Hammershøj, P.; Sørensen, T. J.; Han, B.-H.; Laursen, B. W. J. Org. Chem. 2012, 77, 5606-5612. doi:10.1021/jo3007732

22. Laursen, B. W.; Reynisson, J.; Mikkelsen, K. V.; Bechgaard, K.; Harrit, N. Photochem. Photobiol. Sci. 2005, 4, 568-576. doi:10.1039/b501584g

23. Bogh, S. A.; Simmermacher, M.; Westberg, M.; Bregnhøj, M.; Rosenberg, M.; De Vico, L.; Veiga, M.; Laursen, B. W.; Ogilby, P. R.; Sauer, S. P. A.; Sørensen, T. J. ACS Omega 2017, 2, 193-203. doi:10.1021/acsomega.6b00211

24. Bogh, S. A.; Bora, I.; Rosenberg, M.; Thyrhaug, E.; Laursen, B. W.; Sørensen, T. J. Methods Appl. Fluoresc. 2015, 3, 045001. doi:10.1088/2050-6120/3/4/045001

25. Rich, R. M.; Stankowska, D. L.; Maliwal, B. P.; Sørensen, T. J.; Laursen, B. W.; Krishnamoorthy, R. R.; Gryczynski, Z.; Borejdo, J.; Gryczynski, I.; Fudala, R. Anal. Bioanal. Chem. 2013, 405, 2065-2075. doi:10.1007/s00216-012-6623-1

26. Rich, R. M.; Mummert, M.; Gryczynski, Z.; Borejdo, J.; Sørensen, T. J.; Laursen, B. W.; Foldes-Papp, Z.; Gryczynski, I.; Fudala, R. Anal. Bioanal. Chem. 2013, 405, 4887-4894. doi:10.1007/s00216-013-6879-0

27. Hall, M. D.; Yasgar, A.; Peryea, T.; Braisted, J. C.; Jadhav, A.; Simeonov, A.; Coussens, N. P. Methods Appl. Fluoresc. 2016, 4, 022001. doi:10.1088/2050-6120/4/2/022001

28. Sørensen, T. J.; Thyrhaug, E.; Szabelski, M.; Luchowski, R.; Gryczynski, I.; Gryczynski, Z.; Laursen, B. W. Methods Appl. Fluoresc. 2013, 1, 025001. doi:10.1088/2050-6120/1/2/025001

29. Wada, M.; Konishi, H.; Kirishima, K.; Takeuchi, H.; Natsume, S.; Erabi, T. Bull. Chem. Soc. Jpn. 1997, 70, 2737-2741. doi:10.1246/bcsj.70.2737

30. Laursen, B. W.; Nørgaard, K.; Reitzel, N.; Simonsen, J. B.; Nielsen, C. B.; Als-Nielsen, J.; Bjørnholm, T.; Sølling, T. I.; Nielsen, M. M.; Bunk, O.; Kjaer, K.; Tchebotareva, N.; Watson, M. D.; Müllen, K.; Piris, J. Langmuir 2004, 20, 4139-4146. doi:10.1021/la049944i

31. Sørensen, T. J.; Laursen, B. W. J. Org. Chem. 2010, 75, 6182-6190. doi:10.1021/jo1009917

32. Martin, J. C.; Smith, R. G. J. Am. Chem. Soc. 1964, 86, 2252-2256. doi:10.1021/ja01065a030

33. Laleu, B.; Mobian, P.; Herse, C.; Laursen, B. W.; Hopfgartner, G.; Bernardinelli, G.; Lacour, J. Angew. Chem., Int. Ed. 2005, 44, 1879-1883. doi:10.1002/anie.200462321

34. Herse, C.; Bas, D.; Krebs, F. C.; Bürgi, T.; Weber, J.; Wesolowski, T.; Laursen, B. W.; Lacour, J. Angew. Chem., Int. Ed. 2003, 42, 3162-3166. doi:10.1002/anie.200351443 
35. Bosson, J.; Labrador, G. M.; Pascal, S.; Miannay, F.-A.; Yushchenko, O.; Li, H.; Bouffier, L.; Sojic, N.; Tovar, R. C.; Muller, G.; Jacquemin, D.; Laurent, A. D.; Le Guennic, B.; Vauthey, E.; Lacour, J. Chem. - Eur. J. 2016, 22, 18394-18403. doi:10.1002/chem.201603591

36. Nicolas, C.; Bernardinelli, G.; Lacour, J. J. Phys. Org. Chem. 2010, 23, 1049-1056. doi:10.1002/poc. 1753

37. Rosenberg, M.; Rostgaard, K. R.; Liao, Z.; Madsen, A. Ø.; Martinez, K. L.; Vosch, T.; Laursen, B. W. Chem. Sci. 2018, 9 , 3122-3130. doi:10.1039/c8sc00089a

38. Rosenberg, M.; Santella, M.; Bogh, S. A.; Muñoz, A. V.; Andersen, H. O. B.; Hammerich, O.; Bora, I.; Lincke, K.; Laursen, B. W. J. Org. Chem. 2019, 84, 2556-2567. doi:10.1021/acs.joc.8b02978

39. Simonsen, J. B.; Kjær, K.; Howes, P.; Nørgaard, K.; Bjørnholm, T.; Harrit, N.; Laursen, B. W. Langmuir 2009, 25, 3584-3592. doi:10.1021/la803733s

40. Hansch, C.; Leo, A.; Taft, R. W. Chem. Rev. 1991, 91, 165-195. doi:10.1021/cr00002a004

41. Brown, H. C.; Okamoto, Y. J. Am. Chem. Soc. 1958, 80, 4979-4987. doi:10.1021/ja01551a055

42. Laleu, B.; Herse, C.; Laursen, B. W.; Bernardinelli, G.; Lacour, J. J. Org. Chem. 2003, 68, 6304-6308. doi:10.1021/jo0345998

43. Drexhage, K. H. Structure and Properties of Laser Dyes. In Dye Lasers; Schäfer, F. P., Ed.; Topics in Applied Physics, Vol. 1; Springer: Berlin, Heidelberg, Germany, 1973; pp 144-193. doi:10.1007/978-3-662-11579-4_4

44. Griffiths, J. Colour and Constitution of Organic Molecules; Academic Press: London, 1976.

45. Sørensen, T. J.; Kilså, K.; Laursen, B. W. Chem. - Eur. J. 2015, 21 , 8521-8529. doi:10.1002/chem.201500355

46. Sørensen, T. J.; Shi, D.; Laursen, B. W. Chem. - Eur. J. 2016, 22, 7046-7049. doi:10.1002/chem.201600496

47. Westerlund, F.; Elm, J.; Lykkebo, J.; Carlsson, N.; Thyrhaug, E.; Åkerman, B.; Sørensen, T. J.; Mikkelsen, K. V.; Laursen, B. W. Photochem. Photobiol. Sci. 2011, 10, 1963-1973. doi:10.1039/c1pp05253e

48. Lueck, H. B.; McHale, J. L.; Edwards, W. D. J. Am. Chem. Soc. 1992, 114, 2342-2348. doi:10.1021/ja00033a007

49. Lewis, L. M.; Indig, G. L. Dyes Pigm. 2000, 46, 145-154. doi:10.1016/s0143-7208(00)00049-8

50. Strickler, S. J.; Berg, R. A. J. Chem. Phys. 1962, 37, 814-822. doi:10.1063/1.1733166

51. Kotaskova, M.; Osman Oglou, O.; Helm, M. Org. Biomol. Chem. 2014, 12, 3816-3820. doi:10.1039/c4ob00533c

\section{License and Terms}

This is an Open Access article under the terms of the Creative Commons Attribution License (http://creativecommons.org/licenses/by/4.0). Please note that the reuse, redistribution and reproduction in particular requires that the authors and source are credited.

The license is subject to the Beilstein Journal of Organic Chemistry terms and conditions:

(https://www.beilstein-journals.org/bjoc)

The definitive version of this article is the electronic one which can be found at:

doi:10.3762/bjoc. 15.210 